ACTA UNIVERSITATIS LODZIENSIS

FOLIA LITTERARIA POLONICA 5(35) 2016

http://dx.doi.org/10.18778/1505-9057.35.13

Krzysztof Grzegorzewski*

\title{
News in Television Broadcasts
}

The word "news" is translated into Polish as a "mention" (pol. "wzmianka"). Let us then begin with a definition of the mention from the "Dictionary of Media Terminology":

Mention, flash, news - as an informational genre usually answers only three questions: who? what? where? concerning a single fact or event. The entire mention mostly consists of one or two sentences. Its author focuses on the most important detail of an event. The mention is an element of a chronicle, of highlights of the day, last week, or month, and is, therefore, usually included in dailies (less often in periodicals) or reported on the radio or television immediately after an event by a news agency. In this case, it concerns facts of exceptional significance or connected with well-known figures.

Mentions are also a part of leads. Radio and television are dominant in terms of how fast the "news" is conveyed. The mention replaced the dispatch under the influence of the development of electronic media ${ }^{1}$.

From the point of view of electronic media, we are interested in the news "reported on the radio or television immediately after an event". The question remains how to recognize that this message is indeed of "exceptional significance" - and whether the same can be said about every item of news.

There is no doubt that news is most frequently devoted to negative events. Andrew Boyd lists a few characteristic features of information that interests us:

- proximity (in a territorial sense - that is why the majority of news magazines begin with national information; as a matter of fact, they are dominant);

- relevance (defined as the interest of as many social groups as possible - the more people who are interested in the message, the more important it is);

- immediacy;

* Dr, e-mail: krzysztof.grzegorzewski@uni.lodz.pl; The University of Lodz, Faculty of Philology, Department of Journalism and Communication; ul. Pomorska 171/173, 90-236 Łódź.

1 „Słownik terminologii medialnej”, ed. W. Pisarek, Universitas, Warsaw 2006, p. 237. 
- interest (closely connected with the manner of conveying information: emphasizing the most important, adding the aspect of sensationalism - here also through image);

- drama (danger, emotions, adventure, conflict - but, unfortunately, also brutalization and aggression);

- entertainment (the problem of all infotainment news; "faits divers" (Eng. news items) must stand out by being surprising or containing an original punch line. What is more, spotting someone else's slip-ups may also be entertaining) ${ }^{3}$.

Political character also belongs in these categories - and is unfairly disregarded by Boyd. Examination of the leading Polish news programmes immediately reveals that they are concerned with politics. Whenever „Fakty” (TVN) and „Wiadomości” (TVP1) are compared, the first three news items are almost always devoted to it. The majority of information on news channels (especially in TVN24) is of a political character; TV news but also commentaries is created on that basis. News is often trivial: someone says something unpleasant about someone else, and it almost instantly becomes breaking news. The popularity of the so-called Olewnik case is further evidence. It was a criminal event (kidnapping and financial murder), in addition very old (2002), but its popularity is determined by the fact that it has numerous political undercurrents.

In this sense, everything which is, even by definition, political may become news. There are a few regularities:

- political events may be trivial (in the sense of their consequences), but must be spectacular;

- they must be negative, without exception;

- they must concern famous people, and even better: commonly considered to be disliked (cf. the examples of events concerning Jarosław Kaczyński and his party Law and Justice).

This regularity may be extended to other categories of information connected with important people. The more controversial they are (that is the more negative emotions they evoke), the better. A relatively trivial story about an argument in a Lufthansa aeroplane involving Jan Maria Rokita became a news item; one of the passengers recorded the politician shouting as he was led out by the police: "You are Polish - help me! Germans are beating me up!".

\footnotetext{
${ }^{2}$ However, it would be more appropriate to call this feature a spectacular nature; captain Wrona's landing with a Boeing aeroplane after its landing gear failed was a positive event, unusual, but predominantly spectacular - especially because a TVN camera, which was at the airport, recorded this landing very accurately. Perhaps it is the precision of recording that contributed to its spectacular nature, which translated into the attractiveness of the news item, in spite of the lack of a negative overtone.

${ }^{3}$ A. Boyd, „Dziennikarstwo radiowo-telewizyjne. Techniki tworzenia programów informacyjnych", transl. A. Sadza, Wydawnictwo Uniwersytetu Jagiellońskiego, Cracow 2006, pp. 24-30.
} 
It is sometimes enough that even a little-known person behaves in a way that is not accepted by public opinion. Thus, a news story was created from an incident in which Adam Darski, a previously niche musician in the black metal band Behemoth, tore up a Bible during a concert. Darski himself became a celebrity, even though his musical career had nothing in common with mass culture. This was caused by the mechanisms described by John B. Thompson ${ }^{4}$, though the event was not political. Incidentally, it triggered numerous comments from politicians and political columnists, who considered this matter important enough to repeatedly come back to it. After all, everything happened during a concert, which was not even reported or transmitted in the media (the photographs were taken with a mobile phone). This performance was not primarily addressed to everyone.

Let us add that trivial but mysterious events -sometimes even provided in a very sensational way - may become news. In addition, the status of the event rises if it is concerned with politics. The news that Samoobrona MP Renata Beger had conversations with Law and Justice politicians about moving over to their party in exchange for the position of secretary of state provoked a scandal in Poland. The information resulted in a media frenzy, mutual accusations and on-air arguments. The case of "the tapes of truth" did not cause any political or penal consequences.

It is also noticeable that similar events (Bartosz Arłukowicz's defection to Civic Platform in exchange for the position of Prime Minister's plenipotentiary for combatting social exclusion and Health Minister, or the defection of Joanna Kluzik-Rostkowska to the same party in exchange for the first position on this party's list in Rybnik, meaning guaranteed selection to parliament) did not cause such a scandal. The media obviously informed about them, but in a different way. Therefore, it may be claimed that more is - as it seems - "appropriate" for parties and politicians who are commonly liked.

Boyd enumerates the following types of information:

- emergencies,

- crime,

- local and national government (usually central in the case of Poland),

- planning and developments,

- conflict and controversy (in Poland especially political),

- pressure groups (their activities are reported - and the more brutal they are, the more space is devoted to them),

- industry,

- health,

${ }^{4}$ J.B. Thompson, „Skandal polityczny. Władza i jawność w epoce medialnej”, transl. M. Habura, Wydawnictwa Naukowe PWN, Warsaw 2010. 
- human interest (usually titbits),

- personalities,

- sport,

- special local interest.

On the national level, these last become news very rarely; they must be exceptionally sensational, dramatic and negative or unusually interesting (the singing of train timetables at Łódź Fabryczna railway station the day before it was closed, reported by TVN24, is an example of such news). It does no harm for the news to be original.

In extreme cases, even weather information may become a news item. These kinds of information are essential but equally unnoticeable; they only become news when extreme phenomena occur. Occasionally a news channel (such as e.g. TVN24) devotes ordinary editions of programmes to normal winter phenomena such as heavy snowfalls; persuasive headlines appear at that time e.g.: "Winter attacks!" or similar. While violent storms that cause great losses are indeed extreme, snowfalls during winter should not be surprising. It is worth considering whether this is a case of creating news from nothing - the effect of the existence of 24-hour TV news stations.

Disregarding business is a distinct mistake in Boyd's study.

Business information (even though business channels are considered to be boring and addressed to a narrow group of wealthy and influential people) can be interesting, since it tends to become extreme; for example, the disproportionate increase in the Swiss franc's value (and the wishful slogan appearing on TV screens: "Get lost, franc"). Business information also becomes significant in the abnormal situation of a global economic crisis - at such a time journalists manage to persuade the audience that this news concerns everyone.

It is worth expanding the above characterization of news with a few general remarks regarding television and the problems of its reception - in connection with Giovanni Sartori's essay ${ }^{5}$. If we refer to the basic features of information provided on television (according to Wiesław Godzic: negativity, personalization, locality, vivid character of news and simplicity of the message), then it can be said that it is intended for a recipient who predominantly perceives images and thinks with images. Homo videns (as opposed to homo sapiens) is a person characterized by visual thinking, characteristic of a primitive culture and not based on symbols or creating abstracts. Sartori clearly juxtaposes these two categories.

What does the impoverishment of the cognitive process consist in? Sartori assumes that "the majority of cognitive and theoretical vocabulary com-

${ }^{5}$ G. Sartori, „Homo videns. Telewizja i postmyślenie”, transl. J. Uszyński, Wydawnictwa Uniwersytetu Warszawskiego, Warsaw 2007. 
prises abstract concepts, which do not clearly correspond to visible things and whose significance does not come down to images, nor is it translated into them". Obviously, one may try to visualise some abstracts: unemployment in the form of a queue of poorly dressed people standing in front of an employment agency, poverty in the shape of a tramp. Unfortunately, this substantially simplifies the problem. Therefore, intellectual and cognitive development must proceed from something concrete to concepts, symbols, abstracts. According to Sartori, television teaches the opposite of that - it reverses the process of development, leads to a return to visual thinking, that is the simplest way of conveying stimuli by means of stimulating the senses (here: image and sound, though the ability to render depth [3D], and even complement it with smell [4D], is starting to appear - however, fortunately, not with reference to the news yet). This is how Sartori understands the impoverishment of the cognitive process; in this sense, he considers the development of television as a medium to be a regression.

If we approach news from this point of view, then its nature seems to confirm this thesis. The vividness, characteristic of news and messages, does not have to favour the understanding of the phenomena they are a consequence of - on the contrary, if they are not well explained, it may make them difficult, simplifying their understanding. At this point, the role of journalists should be recognized - the other problem is how they actually fulfil the role of "guides in the world of news".

Misunderstanding the problem of the relevance of information may impoverish the cognitive needs of recipients (reduced, according to Sartori, to only their closest surroundings) - and since cognitive needs are lower, then intellectual ones are as well. The features of news classified by Wiesław Godzic $^{6}$, such as e.g. personalization or matter-of-factness, will result in viewers becoming inclined to perceive certain important phenomena in a simplified way: they will associate unemployment with people standing in the queue to employment agency, but they will not be able to capture the essence of this phenomenon, answer the question of why it exists, how to deal with and how to fight it. Simplicity may be easily mistaken for an excessive simplification of the message. The problem connected with watching negative information is described by, among others, Marek Krajewski ${ }^{7}$. Presenting negative and brutal news ceaselessly makes the messages become more and more aggressive; when a means of expression is exhausted, the reporter will naturally reach for new, even stronger ones.

\footnotetext{
${ }^{6}$ W. Godzic, „Telewizja i jej gatunki. Po Wielkim Bracie”, Universitas, Cracow 2004.

${ }^{7}$ M. Krajewski, „Okrucieństwo w telewizji, okrucieństwo telewizji”, in: „Od kontrkultury do popkultury”, ed. M. Golka, Wydawnictwo Fundacji Humaniora, Poznan 2002.
} 
At the margin of considerations regarding news, it is worth raising the question of journalistic responsibility. Agnieszka and Stanisław Gałkowski ${ }^{8}$ distinguish its three models:

a) artistic responsibility (a journalist has the right to his/her own forms of expression, judgements and emotions, and the media are treated as their carriers; this approach to the problem de facto frees journalists of any responsibility);

b) professional responsibility (it results only from the contract between a journalist and his employer; in this sense, the published materials may even be unethical or scandalous, but as long as they fulfil the terms of the contract, that is affect the audience ratings and market share, the journalist carries out his/her responsibilities well)

c) responsibility of the "fourth power" (the media and journalists are treated as a power which influences the decisions made by society, also those regarding elections; it is a responsibility perceived in the social sense, to some extent identical with a politician's responsibility).

The author concludes that in the case of journalists, we should talk of the overlapping of all of these models. Journalists would prefer not to be responsible for anything (model A), be evaluated and rewarded well for professionalism towards their employer (model B) and have access to information and all rights essential to influence the decisive processes in society (granted by model C).

The remarks made by the authors regarding journalistic responsibility constitute a contribution to a discussion about news on Polish television. However, a few regularities come to mind:

News in Polish television is - as in other countries - predominantly negative. The aforementioned heroic landing without landing gear at Okęcie is an exception that confirms the rule.

The functioning of news is closely dependent on widely understood "attractiveness", which is measured by telemetric audience research ${ }^{9}$ as long as a subject interests viewers, the editors of news programmes search for new information or repeat the old and add commentaries; public affairs programmes are also devoted to such subjects.

News may be trivial or irrelevant from the point of view of life and the informational needs of the ordinary viewer - the event of the day may involve a declaration by Jarosław Kaczyński, chairman of Law and Justice, a political defection,

${ }^{8}$ A. Gałkowska, S. Gałkowski, „Polityczna odpowiedzialność dziennikarska”, in: „Media a polityka”, ed. M. Szpunar, Wydawnictwo Wyższej Szkoły Informatyki i Zarządzania, Rzeszow 2007, pp. $75-90$.

${ }^{9}$ Every news channel undergoes audience research performed with the telemetric method on a random group of viewers. The research is analysed in detail and conclusions are used while creating new programmes. This information comes from the author's conversation with Bogdan Rymanowski, Warsaw, 22.03. 2012; a recording is in the author's archive. 
a controversial statement by MPs Janusz Palikot or Stefan Niesiołowski, or finally the death of two giraffes in Łódź Zoo. The tone of such information in the media may be as strong as the tone of matters subjectively more important or concerning the viewers to a greater extent.

The essence of news is that it becomes outdated very quickly - all subsequent information, regardless of its importance, causes the old to be taken off the air almost completely, and - as one may think - the viewers should immediately forget about it.

\section{Bibliography}

Boyd A., „Dziennikarstwo radiowo-telewizyjne. Techniki tworzenia programów informacyjnych”, transl. A. Sadza, Wydawnictwo Uniwersytetu Jagiellońskiego, Cracow 2006.

Gałkowska A., Gałkowski S., „Polityczna odpowiedzialność dziennikarska”, in: „Media a polityka”, ed. M. Szpunar, Wydawnictwo Wyższej Szkoły Informatyki i Zarządzania, Rzeszow 2007, pp. 75-90.

Godzic W., „Telewizja i jej gatunki. Po Wielkim Bracie”, Universitas, Cracow 2004.

Krajewski M., „Okrucieństwo w telewizji, okrucieństwo telewizji”, in: „Od kontrkultury do popkultury”, ed. M. Golka, Wydawnictwo Fundacji Humaniora, Poznan 2002, pp. 29-57.

Sartori G., „Homo videns. Telewizja i postmyślenie”, transl. J. Uszyński, Wydawnictwa Uniwersytetu Warszawskiego, Warsaw 2007.

„Słownik terminologii medialnej”, ed. Pisarek, Universitas, Warsaw 2006.

Thompson J.B., „Skandal polityczny. Władza i jawność w epoce medialnej”, transl. M. Habura, Wydawnictwa Naukowe PWN, Warsaw 2010.

\section{Krzysztof Grzegorzewski}

\section{News in Television Broadcasts}

(Summary)

The text is focused on the characteristics of news in daily TV programmes, such as the news or broadcasts on round-the-clock television (e.g. TVN 24). The author proposes a definition of news and tries to approach its intrinsic features in Polish conditions, illustrating the discussion with examples. A full description of news (considering such problems as content and the most important characteristics) makes it possible to systematize an event and analyse news in the Polish mass media.

Keywords: news, news values, television broadcast. 